\title{
Effects of Milling Time on the Hydrogen Storage Properties of Mg-based Transition Metals-added Alloys
}

\author{
Hye Ryoung PARK ${ }^{1}$, Sung Nam KWON ${ }^{2}$, Myoung Youp SONG ${ }^{3 *}$ \\ ${ }^{1}$ School of Chemical Engineering, Chonnam National University, 77 Yongbong-ro Buk-gu Gwangju, 61186, Republic of \\ Korea \\ ${ }^{2}$ Department of Flexible and Printable Electronics, Professional Graduate School of Flexible and Printable, Chonbuk \\ National University, 567 Baekje-daero Deokjin-gu Jeonju, 54896, Republic of Korea \\ ${ }^{3}$ Division of Advanced Materials Engineering, Hydrogen \& Fuel Cell Research Center, Engineering Research Institute, \\ Chonbuk National University, 567 Baekje-daero Deokjin-gu Jeonju, 54896, Republic of Korea
}

crossref http://dx.doi.org/10.5755/j01.ms.24.2.18395

Received 16 June 2017; accepted 23 August 2017

\begin{abstract}
In this work, $\mathrm{Mg}$ was employed as a starting material. $\mathrm{Ni}, \mathrm{Fe}$ and $\mathrm{Ti}$ were selected as additives to improve hydriding and dehydriding rates of $\mathrm{Mg}$. A 90 wt. $\% \mathrm{Mg}+5$ wt. $\% \mathrm{Ni}+2.5$ wt. $\% \mathrm{Fe}+2.5$ wt. $\%$ Ti sample [named $90 \mathrm{Mg}-\mathrm{Ni}-\mathrm{Fe}-\mathrm{Ti}(8 \mathrm{~h})$ ] was prepared by mechanical grinding under $\mathrm{H}_{2}$ atmosphere (reactive mechanical grinding) for $8 \mathrm{~h}$, using a planetary ball mill. The hydrogen-storage properties of the prepared sample were then investigated and compared with those of a 90 wt. $\% \mathrm{Mg}+5 \mathrm{wt} . \% \mathrm{Ni}+2.5 \mathrm{wt} . \% \mathrm{Fe}+2.5 \mathrm{wt} . \%$ Ti sample previously studied by preparing via reactive mechanical grinding for $4 \mathrm{~h}$ [named $90 \mathrm{Mg}-\mathrm{Ni}-\mathrm{Fe}-\mathrm{Ti}(4 \mathrm{~h})$ ]. Reactive mechanical grinding for a longer time (for $8 \mathrm{~h}$ ), compared with that for $4 \mathrm{~h}$, intensified the effects of reactive mechanical grinding. After activation, $90 \mathrm{Mg}-\mathrm{Ni}-\mathrm{Fe}-\mathrm{Ti}(4 \mathrm{~h})$ had higher initial hydriding and dehydriding rates and larger quantities of hydrogen absorbed and released for $60 \mathrm{~min}$ than 90Mg-Ni-Fe-Ti $(8 \mathrm{~h}$ ). Prolonged milling (for example, for $8 \mathrm{~h}$ ) is considered to bring about coalescence of particles which is caused by severe plastic deformation of ductile $\mathrm{Mg}$ particles. The stronger effect of hydriding-dehydriding cycling and the less compact agglomeration are believed to lead to the higher initial hydriding and dehydriding rates and the larger quantities of hydrogen absorbed and released for $60 \mathrm{~min}$ of $90 \mathrm{Mg}-\mathrm{Ni}-\mathrm{Fe}-\mathrm{Ti}$ ( $4 \mathrm{~h}$ ) than those of $90 \mathrm{Mg}-\mathrm{Ni}-\mathrm{Fe}-\mathrm{Ti}(8 \mathrm{~h})$ after $\mathrm{n}=2$.

Keywords: hydrogen absorption and desorption kinetics, $\mathrm{Mg}-\mathrm{Ni}-\mathrm{Fe}-\mathrm{Ti}$, reactive mechanical grinding, milling conditions, microstructure.
\end{abstract}

\section{INTRODUCTION}

Storing hydrogen as a gas, liquid hydrogen storage, the physisorption of hydrogen, and storing it in the form of metal hydrides, complex hydrides, and via chemical reactions are currently studied [1].

Magnesium, one of the prospective hydrogen storage materials, has a high hydrogen storage capacity of about $7.6 \mathrm{wt} . \%$ and is abundant in the earth's crust. However, its hydrogen absorption and desorption kinetics are very slow and occur at very high temperatures (at least $623 \sim 673 \mathrm{~K}$ and over a period of several hours).

Many studies have been conducted in an attempt to improve the reaction kinetics of magnesium with hydrogen by adding some catalytic materials and performing mechanical treatment and/or alloying. For example, elements Pd [2], Ti [3] $\mathrm{Co}, \mathrm{Ni}$, or $\mathrm{Fe}[4,5], \mathrm{Ni}, \mathrm{Fe}$, and/or Ti $[6-8]$, graphite $[9,10]$, and transition metals and/or compounds to $\mathrm{Mg}$ or $\mathrm{MgH}_{2}$ [11-18] were added. Nucleation can be facilitated by creating active nucleation sites and defects; these are made by mechanical treatment and/or alloying with additives [19]. The diffusion distance of hydrogen can be decreased by the mechanical treatment and/or alloying of $\mathrm{Mg}$ with additives, thereby reducing the magnesium particle size [20]. In addition, the hydrogen mobility can be improved by additives that create

\footnotetext{
* Corresponding author. Tel.: +82-63-270-2379; fax: +82-63-270-2386

E-mail address: songmy@jbnu.ac.kr (M.Y.Song)
}

microscopic paths of hydrogen [20]. Consequently, a rough surface of magnesium possessing many cracks and defects is considered more advantageous for hydrogen absorption [21].

As a process of mechanical treatment and/or alloying with additives, we chose mechanical grinding under $\mathrm{H}_{2}$ atmosphere (reactive mechanical grinding), which is expected to create defects, produce paths of hydrogen, and decrease particle size. We were in particular interested in the milling time, one of the important factors of reactive mechanical grinding.

In this work, $\mathrm{Mg}$ was used as a starting material. $\mathrm{Ni}, \mathrm{Fe}$ and $\mathrm{Ti}$ were chosen as additives to enhance hydriding and dehydriding rates of $\mathrm{Mg}$. $\mathrm{Ni}$ is known to form $\mathrm{Mg}_{2} \mathrm{NiH}_{4}$ which has higher hydriding and dehydriding rates than magnesium. $\mathrm{Fe}$ is cheap as compared with $\mathrm{Ni}$, and may act active site for the dissociative chemisorption of $\mathrm{H}_{2}$ [22]. $\mathrm{Ti}$ is believed to increase the hydriding and dehydriding rates when it was added. A 90 wt. $\% \mathrm{Mg}+5$ wt. $\% \mathrm{Ni}+2.5$ wt.\% Fe+2.5 wt.\% $\%$ sample [named $90 \mathrm{Mg}-\mathrm{Ni}-\mathrm{Fe}-\mathrm{Ti}(8 \mathrm{~h})$ ] was prepared by reactive mechanical grinding for $8 \mathrm{~h}$, using a planetary ball mill. The hydrogen-storage properties of the prepared sample were then investigated and compared with those of $\begin{array}{lllll}\text { a } & 90 \text { wt. } \% \quad \mathrm{Mg}+5 \text { wt. } \% & \mathrm{Ni}+2.5 \text { wt.\% } & \mathrm{Fe}+\end{array}$ +2.5 wt. $\%$ Ti sample [23] previously studied by preparing via reactive mechanical grinding for $4 \mathrm{~h}$ [named 90Mg-Ni-Fe-Ti (4 h)]. 


\section{EXPERIMENTAL DETAILS}

The starting materials were pure $\mathrm{Mg}$ (particle size $75-150 \mu \mathrm{m}$, purity $99.6 \%$ ), $\mathrm{Ni}$ (average particle size $2.2 \sim 3.0 \mu \mathrm{m}$, purity $99.9 \%$ ), Fe (particle size < $10 \mu \mathrm{m}$, purity $99.9 \%$ ), and $\mathrm{Ti}$ (particle size $<45 \mu \mathrm{m}$, purity $99.98 \%$ ) powders. $\mathrm{Mg}, \mathrm{Ni}$ and Fe powders were purchased from Alfa Aesar GmbH (Germany), and Ti powder was provided by Sigma-Aldrich (USA).

In our previous work, the optimum conditions for reactive mechanical grinding were the sample weight to ball weight ratio of $1 / 45$ and a disc revolution speed of $250 \mathrm{rpm}$ [24]. These powders were mixed to obtain the composition $90 \mathrm{wt} . \% \mathrm{Mg}+5 \mathrm{wt} . \% \mathrm{Ni}+2.5 \mathrm{wt} . \% \mathrm{Fe}+$ $+2.5 \mathrm{wt} \% \mathrm{Ti}$. The total weight of the mixture was $8 \mathrm{~g}$. The mixture was put into a stainless steel container with 105 hardened steel balls (total weight: $360 \mathrm{~g}$ ), and the container with a volume of $250 \mathrm{ml}$ was then sealed hermetically. All handling was performed in a glove box filled with Ar. Mechanical grinding was performed in a planetary ball mill at a disc revolution speed of $250 \mathrm{rpm}$ under $12 \mathrm{bar}_{2}$. After repeating milling for $15 \mathrm{~min}$ and pausing for $5 \mathrm{~min}$ four times, the container was refilled with hydrogen up to a pressure of 12 bar $\mathrm{H}_{2}$. Milling, pausing, and refilling of hydrogen were repeated, leading to the total milling time of $8 \mathrm{~h}$.

The quantities of hydrogen absorbed or released were measured as a function of time in a Sieverts' type apparatus [24] under nearly constant hydrogen pressures. The powders as-milled and after hydriding-dehydriding cycling were characterized by X-ray diffraction (XRD), using a Rigaku D/MAX 2500 powder diffractometer with $\mathrm{Cu} \mathrm{Ka}$ radiation. The microstructures of the particles were observed by a JSM-6400 scanning electron microscope (SEM) operated at $20 \mathrm{kV}$.

\section{RESULTS AND DISCUSSION}

The absorbed hydrogen quantity is expressed as the percentage of the absorbed hydrogen with respect to the sample weight. Fig. 1 shows the absorbed hydrogen quantity vs. time curves at $573 \mathrm{~K}$ under 12 bar $\mathrm{H}_{2}$ at the number of cycles of one $(n=1)$ for the $90 \mathrm{Mg}-\mathrm{Ni}-\mathrm{Fe}-\mathrm{Ti}$ (4 h) and 90Mg-Ni-Fe-Ti (8 h) samples.

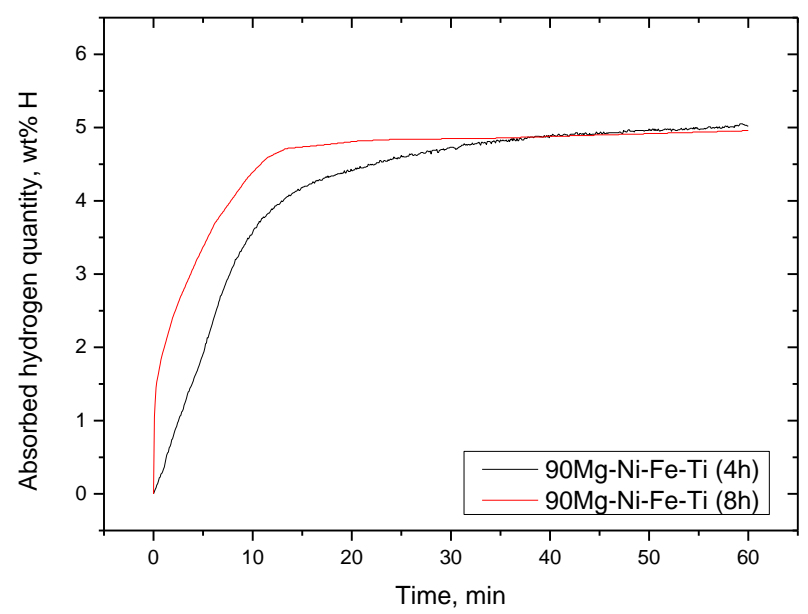

Fig. 1. Absorbed hydrogen quantity vs. time curves at $573 \mathrm{~K}$ under 12 bar $\mathrm{H}_{2}$ at $\mathrm{n}=1$ for the $90 \mathrm{Mg}-\mathrm{Ni}-\mathrm{Fe}-\mathrm{Ti}(4 \mathrm{~h})$ [23] and $90 \mathrm{Mg}-\mathrm{Ni}-\mathrm{Fe}-\mathrm{Ti}(8 \mathrm{~h})$ samples
The times of reactive mechanical grinding for the $90 \mathrm{Mg}-\mathrm{Ni}-\mathrm{Fe}-\mathrm{Ti}$ samples were $4 \mathrm{~h}$ and $8 \mathrm{~h}$, respectively. For the $90 \mathrm{Mg}-\mathrm{Ni}-\mathrm{Fe}-\mathrm{Ti}(4 \mathrm{~h})$ [23] and 90Mg-Ni-Fe-Ti (8 h) samples the hydriding rates are quite high in the beginning and then it gets gradually lower. $90 \mathrm{Mg}-\mathrm{Ni}-\mathrm{Fe}-\mathrm{Ti}(8 \mathrm{~h})$ has a higher initial hydriding rate but a slightly smaller quantity of hydrogen absorbed for $60 \mathrm{~min}$ than $90 \mathrm{Mg}-\mathrm{Ni}-\mathrm{Fe}-\mathrm{Ti}$ (4 h). $90 \mathrm{Mg}-\mathrm{Ni}-\mathrm{Fe}-\mathrm{Ti}(8 \mathrm{~h}$ ) absorbs $3.37 \mathrm{wt} \% \mathrm{H}$ for $5 \mathrm{~min}$, $4.39 \mathrm{wt} . \% \mathrm{H}$ for $10 \mathrm{~min}$, and $4.96 \mathrm{wt} . \% \mathrm{H}$ for $60 \mathrm{~min}$. About $67.9 \%$ of the hydrogen absorbed for $60 \mathrm{~min}$ is absorbed for $5 \mathrm{~min}$.

The released hydrogen quantity is also expressed as the percentage of the released hydrogen with respect to the sample weight. The released hydrogen quantity vs. time curves at $573 \mathrm{~K}$ under 1.0 bar $\mathrm{H}_{2}$ at $\mathrm{n}=1$ for the $90 \mathrm{Mg}-\mathrm{Ni}-\mathrm{Fe}-\mathrm{Ti}$ (4 h) [23] and 90Mg-Ni-Fe-Ti (8 h) samples are shown in Fig. 2. The 90Mg-Ni-Fe-Ti $(8 \mathrm{~h})$ sample exhibits quite low dehydriding rate, compared with the $90 \mathrm{Mg}-\mathrm{Ni}-\mathrm{Fe}-\mathrm{Ti}(4 \mathrm{~h})$. 90Mg-Ni-Fe-Ti $(4 \mathrm{~h})$ has a relatively high initial dehydriding rate and then its dehydriding rate decreases gradually from about $25 \mathrm{~min}$. $90 \mathrm{Mg}-\mathrm{Ni}-\mathrm{Fe}-\mathrm{Ti}(4 \mathrm{~h})$ releases $0.52 \mathrm{wt} \% \mathrm{H}$ for $5 \mathrm{~min}$, $1.09 \mathrm{wt} . \% \mathrm{H}$ for $10 \mathrm{~min}, 2.36 \mathrm{wt} \% \mathrm{H}$ for $20 \mathrm{~min}$, and $4.20 \mathrm{wt} . \% \mathrm{H}$ for $60 \mathrm{~min}$.

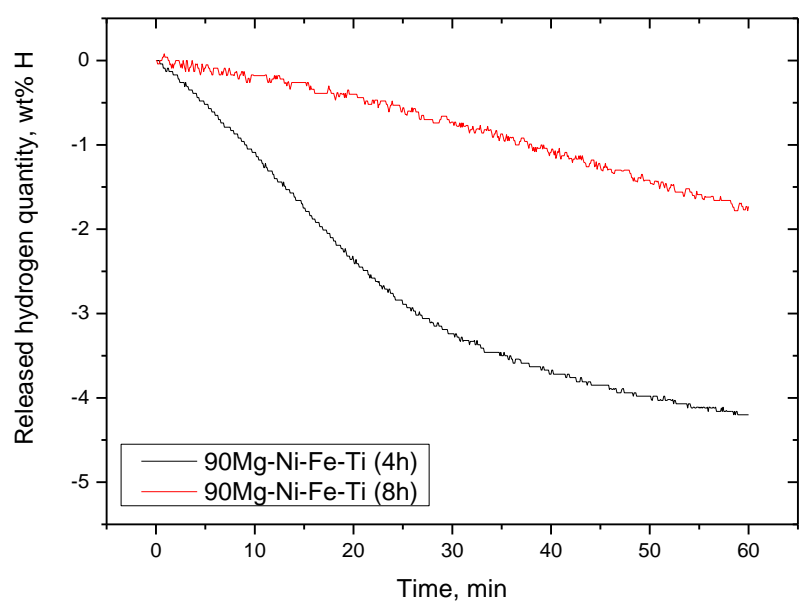

Fig. 2. Released hydrogen quantity vs. time curves at $573 \mathrm{~K}$ under 1.0 bar $\mathrm{H}_{2}$ at $\mathrm{n}=1$ for the $90 \mathrm{Mg}-\mathrm{Ni}-\mathrm{Fe}-\mathrm{Ti}$ (4 h) [23] and $90 \mathrm{Mg}-\mathrm{Ni}-\mathrm{Fe}-\mathrm{Ti}(8 \mathrm{~h})$ samples

At $\mathrm{n}=1$, 90Mg-Ni-Fe-Ti $(4 \mathrm{~h})$ has a lower initial hydriding rate and a slightly larger quantity of hydrogen absorbed for $60 \mathrm{~min}$ than $90 \mathrm{Mg}-\mathrm{Ni}-\mathrm{Fe}-\mathrm{Ti}(8 \mathrm{~h})$, whereas $90 \mathrm{Mg}-\mathrm{Ni}-\mathrm{Fe}-\mathrm{Ti}(4 \mathrm{~h})$ has a higher initial dehydriding rate and a larger quantity of hydrogen released for $60 \mathrm{~min}$ than $90 \mathrm{Mg}-\mathrm{Ni}-\mathrm{Fe}-\mathrm{Ti}(8 \mathrm{~h})$. This is thought to be due to the expansion of the $\mathrm{Mg}$ lattice by hydriding reaction at the first cycle, which separates particles and thus provides the passages for hydrogen.

Table 1 gives the absorbed and released hydrogen quantities (AHQ and RHQ) of the 90Mg-Ni-Fe-Ti ( $4 \mathrm{~h}$ ) and $90 \mathrm{Mg}-\mathrm{Ni}-\mathrm{Fe}-\mathrm{Ti}(8 \mathrm{~h})$ samples at $\mathrm{n}=1$ after 5, 10, 20, 30 and $60 \mathrm{~min}$ for absorption at $573 \mathrm{~K}$ under $12 \mathrm{bar}_{2}$ and for desorption at $573 \mathrm{~K}$ under 1.0 bar $\mathrm{H}_{2}$.

The hydriding rates of the $90 \mathrm{Mg}-\mathrm{Ni}-\mathrm{Fe}-\mathrm{Ti}(4 \mathrm{~h})$ and $90 \mathrm{Mg}-\mathrm{Ni}-\mathrm{Fe}-\mathrm{Ti}(8 \mathrm{~h})$ samples are quite high in the beginning. For $90 \mathrm{Mg}-\mathrm{Ni}-\mathrm{Fe}-\mathrm{Ti}(8 \mathrm{~h})$, about $67.9 \%$ of the hydrogen absorbed for $60 \mathrm{~min}$ is absorbed for $5 \mathrm{~min}$. The 
hydrogen quantities absorbed for $5 \mathrm{~min}$ by these two samples are compared. Fig. 3 presents the variations, with the number of hydriding-dehydriding cycles, of the hydrogen quantity absorbed for $5 \mathrm{~min}$ [AHQ ( $5 \mathrm{~min})$ ] at $573 \mathrm{~K}$ under 12 bar $\mathrm{H}_{2}$ for $90 \mathrm{Mg}-\mathrm{Ni}-\mathrm{Fe}-\mathrm{Ti}(4 \mathrm{~h})$ and 90Mg-Ni-Fe-Ti (8 h).

Table 1. Absorbed and released hydrogen quantities (AHQ and RHQ) of the $90 \mathrm{Mg}-\mathrm{Ni}-\mathrm{Fe}-\mathrm{Ti}(4 \mathrm{~h})$ and $90 \mathrm{Mg}-\mathrm{Ni}-\mathrm{Fe}-\mathrm{Ti}$ $(8 \mathrm{~h})$ samples at $\mathrm{n}=1$ after 5,10,20,30 and $60 \mathrm{~min}$ for

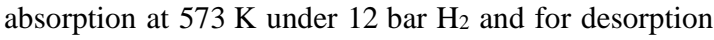
at $573 \mathrm{~K}$ under 1.0 bar $\mathrm{H}_{2}$

\begin{tabular}{|c|c|c|c|c|c|}
\hline \multirow{2}{*}{ Sample } & \multicolumn{5}{|c|}{ AHQ/RHQ, wt.\% H } \\
\cline { 2 - 6 } & $5 \mathrm{~min}$ & $10 \mathrm{~min}$ & $20 \mathrm{~min}$ & $30 \mathrm{~min}$ & $60 \mathrm{~min}$ \\
\hline $\begin{array}{c}90 \mathrm{Mg}- \\
\mathrm{Ni}-\mathrm{Fe}-\mathrm{Ti} \\
(4 \mathrm{~h})\end{array}$ & $1.91 / 0.52$ & $3.57 / 1.09$ & $4.41 / 2.36$ & $4.73 / 3.24$ & $5.02 / 4.20$ \\
\hline $\begin{array}{c}90 \mathrm{Mg}- \\
\mathrm{Ni}-\mathrm{Fe}-\mathrm{Ti} \\
(8 \mathrm{~h})\end{array}$ & $3.37 / 0.09$ & $4.39 / 0.18$ & $4.81 / 0.40$ & $4.85 / 0.73$ & $4.96 / 1.73$ \\
\hline
\end{tabular}

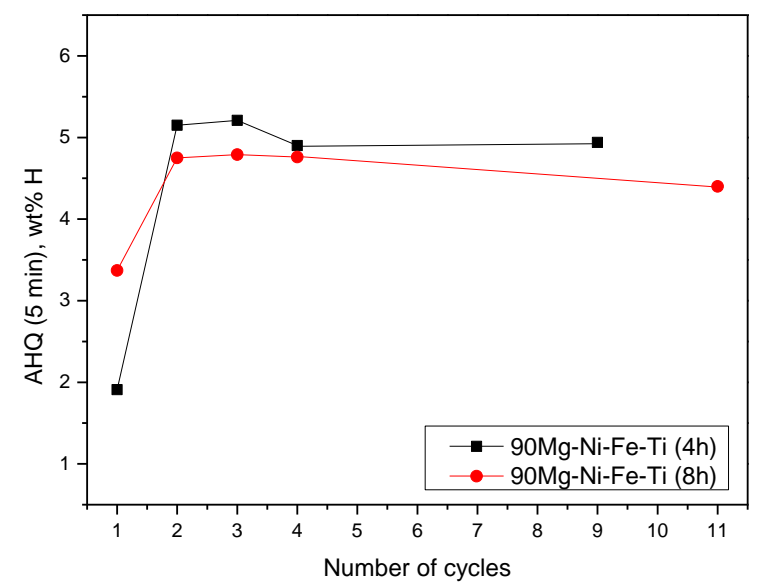

Fig. 3. Variations, with the number of hydriding-dehydriding cycles, of the hydrogen quantity absorbed for $5 \mathrm{~min}$ [AHQ ( $5 \mathrm{~min})$ ] at $573 \mathrm{~K}$ under 12 bar $\mathrm{H}_{2}$ for the $90 \mathrm{Mg}$ $\mathrm{Ni}-\mathrm{Fe}-\mathrm{Ti}(4 \mathrm{~h})$ and $90 \mathrm{Mg}-\mathrm{Ni}-\mathrm{Fe}-\mathrm{Ti}(8 \mathrm{~h})$ samples

At $\mathrm{n}=1,90 \mathrm{Mg}-\mathrm{Ni}-\mathrm{Fe}-\mathrm{Ti}(8 \mathrm{~h})$ absorbs a larger amount of hydrogen for $5 \mathrm{~min}$ than $90 \mathrm{Mg}-\mathrm{Ni}-\mathrm{Fe}-\mathrm{Ti}(4 \mathrm{~h})$, absorbing 3.37 and $1.91 \mathrm{wt} \% \mathrm{H}$, respectively. As the number of hydriding-dehydriding cycles increases, the absorbed hydrogen quantities of $90 \mathrm{Mg}-\mathrm{Ni}-\mathrm{Fe}-\mathrm{Ti}(8 \mathrm{~h})$ and $90 \mathrm{Mg}-\mathrm{Ni}-\mathrm{Fe}-\mathrm{Ti}(4 \mathrm{~h})$ increase and then decrease from $\mathrm{n}=3$. A rapid increase in AHQ ( 5 min) from $n=1$ to $n=2$ is believed due to the expansion of the $\mathrm{Mg}$ lattice by hydriding reaction, causing separation of particles and thus providing the passage for hydrogen.

The fractions of the hydrogen quantities released for $30 \mathrm{~min}$ by the $90 \mathrm{Mg}-\mathrm{Ni}-\mathrm{Fe}-\mathrm{Ti}(4 \mathrm{~h})$ and $90 \mathrm{Mg}-\mathrm{Ni}-\mathrm{Fe}-\mathrm{Ti}$ $(8 \mathrm{~h})$ samples are quite large. The hydrogen quantities released for $30 \mathrm{~min}$ by these two samples are compared. The variations, with the number of hydriding-dehydriding cycles, of the hydrogen quantity released for $30 \mathrm{~min}$ [RHQ (30 $\mathrm{min})$ ] at $573 \mathrm{~K}$ under 1.0 bar $\mathrm{H}_{2}$ for the $90 \mathrm{Mg}-\mathrm{Ni}-\mathrm{Fe}-\mathrm{Ti}(4 \mathrm{~h})$ and $90 \mathrm{Mg}-\mathrm{Ni}-\mathrm{Fe}-\mathrm{Ti}(8 \mathrm{~h})$ are shown in Fig. 4. $90 \mathrm{Mg}-\mathrm{Ni}-\mathrm{Fe}-\mathrm{Ti}(4 \mathrm{~h})$ releases a larger amount of hydrogen for $30 \mathrm{~min}$ than $90 \mathrm{Mg}-\mathrm{Ni}-\mathrm{Fe}-\mathrm{Ti}(8 \mathrm{~h})$, releasing 3.24 and 0.73 wt. $\% H$, respectively, at $n=1$. As the number of hydriding-dehydriding cycles increases, the released hydrogen quantities increase, those of $90 \mathrm{Mg}-\mathrm{Ni}-\mathrm{Fe}-\mathrm{Ti}(4 \mathrm{~h})$ and $90 \mathrm{Mg}-\mathrm{Ni}-\mathrm{Fe}-\mathrm{Ti}(8 \mathrm{~h})$ reaching the maximum values of $3.67 \mathrm{wt} . \% \mathrm{H}($ at $\mathrm{n}=4$ ) and 2.99 wt. $\% \mathrm{H}($ at $\mathrm{n}=3$ ), respectively.

Fig. 3 and Fig. 4 show that the effects of of hydridingdehydriding cycling on the hydriding and dehydriding rates of $90 \mathrm{Mg}-\mathrm{Ni}-\mathrm{Fe}-\mathrm{Ti}(4 \mathrm{~h})$ and $90 \mathrm{Mg}-\mathrm{Ni}-\mathrm{Fe}-\mathrm{Ti}(8 \mathrm{~h})$ are very strong from $n=1$ to $n=2$. The complete activation of these two samples was achieved after about three hydridingdehydriding cycles. The relatively higher initial hydriding rate at $\mathrm{n}=1$ of $90 \mathrm{Mg}-\mathrm{Ni}-\mathrm{Fe}-\mathrm{Ti}(8 \mathrm{~h})$, compared with that of $90 \mathrm{Mg}-\mathrm{Ni}-\mathrm{Fe}-\mathrm{Ti}(4 \mathrm{~h})$, proves that, the effect of reactive mechanical grinding on the hydriding rates of $90 \mathrm{Mg}-\mathrm{Ni}-\mathrm{Fe}-\mathrm{Ti}(8 \mathrm{~h})$ is stronger than that on those of $90 \mathrm{Mg}-\mathrm{Ni}-\mathrm{Fe}-\mathrm{Ti}(4 \mathrm{~h})$. On the other hand, the relatively rapid increase in the value of AHQ (5 min) for $90 \mathrm{Mg}-\mathrm{Ni}-\mathrm{Fe}-\mathrm{Ti}(4 \mathrm{~h})$ as the number of cycles increases from $n=1$ to $n=2$ supports that, the effect of hydridingdehydriding cycling on the hydriding rates of $90 \mathrm{Mg}-\mathrm{Ni}-\mathrm{Fe}-\mathrm{Ti}(4 \mathrm{~h})$ is stronger than that for 90Mg-Ni-Fe-Ti (8 h).

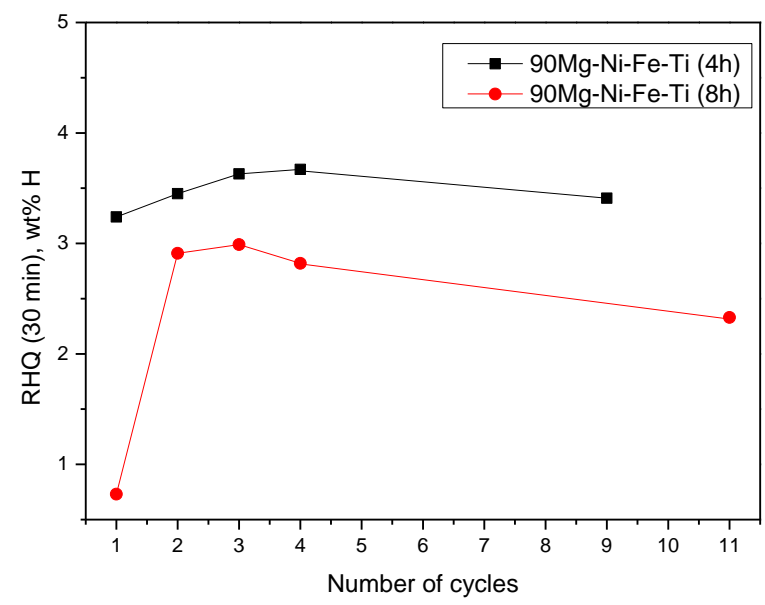

Fig. 4. Variations, with the number of hydriding-dehydriding cycles, of the hydrogen quantity released for $30 \mathrm{~min}$ [RHQ $(30 \mathrm{~min})]$ at $573 \mathrm{~K}$ under $1.0 \mathrm{bar} \mathrm{H}_{2}$ for the $90 \mathrm{Mg}$ $\mathrm{Ni}-\mathrm{Fe}-\mathrm{Ti}(4 \mathrm{~h})$ and $90 \mathrm{Mg}-\mathrm{Ni}-\mathrm{Fe}-\mathrm{Ti}(8 \mathrm{~h})$ samples

Fig. 5 presents the absorbed hydrogen quantity vs. time curves at $573 \mathrm{~K}$ under 12 bar $\mathrm{H}_{2}$ for the activated $90 \mathrm{Mg}-\mathrm{Ni}-\mathrm{Fe}-\mathrm{Ti}$ (4 h) [23] and 90Mg-Ni-Fe-Ti (8 h) samples.

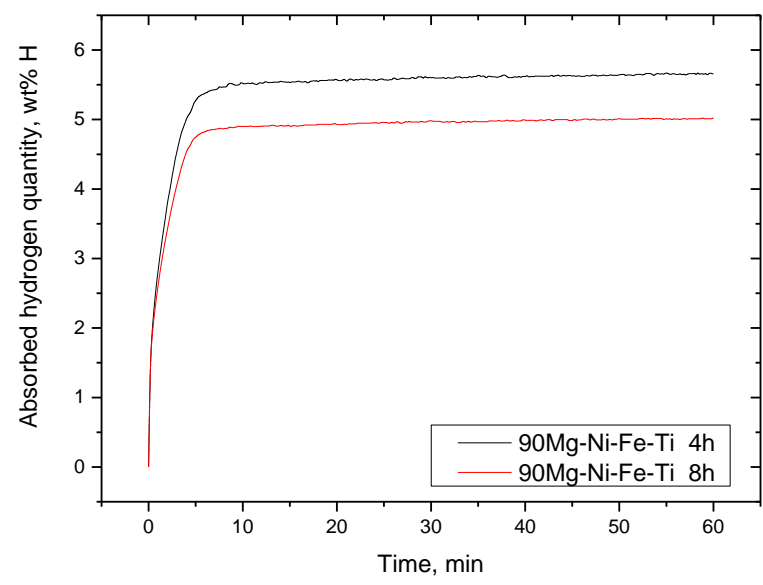

Fig. 5. Absorbed hydrogen quantity vs. time curves at $573 \mathrm{~K}$ 
under 12 bar $\mathrm{H}_{2}$ for the activated $90 \mathrm{Mg}-\mathrm{Ni}-\mathrm{Fe}-\mathrm{Ti}(4 \mathrm{~h})$ [23] and 90Mg-Ni-Fe-Ti (8 h) samples

The hydriding rate is very high in the beginning up to about $5 \mathrm{~min}$. The hydriding rate then decreases rapidly, and after about $5 \mathrm{~min}$ the hydriding rate is extremely low. $90 \mathrm{Mg}-\mathrm{Ni}-\mathrm{Fe}-\mathrm{Ti}(4 \mathrm{~h})$ has a higher initial hydriding rate and a larger absorbed hydrogen quantity for $60 \mathrm{~min}$ than 90Mg-Ni-Fe-Ti $\quad(8 \mathrm{~h}) . \quad$ The activated 90Mg-Ni-Fe-Ti (4 h) sample absorbs $5.21 \mathrm{wt} . \% \mathrm{H}$ for $5 \mathrm{~min}, 5.50 \mathrm{wt} . \% \mathrm{H}$ for $10 \mathrm{~min}, 5.56 \mathrm{wt} . \% \mathrm{H}$ for $20 \mathrm{~min}$, $5.62 \mathrm{wt} . \% \mathrm{H}$ for $30 \mathrm{~min}$, and $5.67 \mathrm{wt} . \% \mathrm{H}$ for $60 \mathrm{~min}$. About $91.9 \%$ of the hydrogen absorbed for $60 \mathrm{~min}$ is absorbed for $5 \mathrm{~min}$.

The released hydrogen quantity vs. time curves at 573 $\mathrm{K}$ under 1.0 bar $\mathrm{H}_{2}$ for the activated $90 \mathrm{Mg}-\mathrm{Ni}-\mathrm{Fe}-\mathrm{Ti}(4 \mathrm{~h})$ [23] and 90Mg-Ni-Fe-Ti (8 h) samples are shown in Fig. 6. $90 \mathrm{Mg}-\mathrm{Ni}-\mathrm{Fe}-\mathrm{Ti}$ (4 h) sample has a higher initial dehydriding rate and a larger released hydrogen quantity for $60 \mathrm{~min}$ than $90 \mathrm{Mg}-\mathrm{Ni}-\mathrm{Fe}-\mathrm{Ti}(8 \mathrm{~h})$. The activated $90 \mathrm{Mg}-\mathrm{Ni}-\mathrm{Fe}-\mathrm{Ti}(4 \mathrm{~h})$ sample releases $0.52 \mathrm{wt} \% \mathrm{H}$ for $5 \mathrm{~min}, 1.09 \mathrm{wt} \% \mathrm{H}$ for $10 \mathrm{~min}, 2.49 \mathrm{wt} . \% \mathrm{H}$ for $20 \mathrm{~min}$, $3.63 \mathrm{wt} . \% \mathrm{H}$ for $30 \mathrm{~min}$, and $4.72 \mathrm{wt} \% \mathrm{H}$ for $60 \mathrm{~min}$.

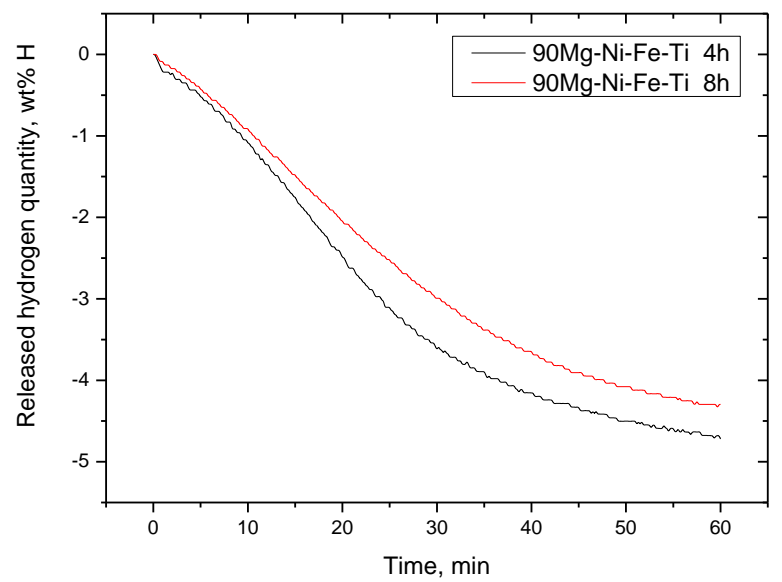

Fig. 6. Released hydrogen quantity vs. time curves at $573 \mathrm{~K}$ under 1.0 bar $\mathrm{H}_{2}$ for the activated $90 \mathrm{Mg}-\mathrm{Ni}-\mathrm{Fe}-\mathrm{Ti}(4 \mathrm{~h})$ [23] and 90Mg-Ni-Fe-Ti (8 h) samples

Table 2 shows the absorbed and released hydrogen quantities (AHQ and RHQ) of the activated 90Mg-Ni-Fe-Ti $(4 \mathrm{~h})$ and $90 \mathrm{Mg}-\mathrm{Ni}-\mathrm{Fe}-\mathrm{Ti}(8 \mathrm{~h})$ samples after 5, 10, 20, 30 and $60 \mathrm{~min}$ for absorption at $573 \mathrm{~K}$ under 12 bar $\mathrm{H}_{2}$ and for desorption at $573 \mathrm{~K}$ under $1.0 \mathrm{bar}$ $\mathrm{H}_{2}$.

Table 2. Absorbed and released hydrogen quantities (AHQ and RHQ) of the activated $90 \mathrm{Mg}-\mathrm{Ni}-\mathrm{Fe}-\mathrm{Ti}(4 \mathrm{~h})$ and $90 \mathrm{Mg}-\mathrm{Ni}-\mathrm{Fe}-\mathrm{Ti}(8 \mathrm{~h})$ samples after 5, 10, 20, 30 and $60 \mathrm{~min}$ for absorption at $573 \mathrm{~K}$ under 12 bar $\mathrm{H}_{2}$ and for desorption at $573 \mathrm{~K}$ under $1.0{\text { bar } \mathrm{H}_{2}}$

\begin{tabular}{|c|c|c|c|c|c|}
\hline \multirow{2}{*}{ Sample } & \multicolumn{5}{|c|}{ AHQ/RHQ, wt.\% H } \\
\cline { 2 - 6 } & $5 \mathrm{~min}$ & $10 \mathrm{~min}$ & $20 \mathrm{~min}$ & $30 \mathrm{~min}$ & $60 \mathrm{~min}$ \\
\hline $\begin{array}{c}90 \mathrm{Mg}- \\
\mathrm{Ni}-\mathrm{Fe}-\mathrm{Ti} \\
(4 \mathrm{~h})\end{array}$ & $5.21 / 0.52$ & $5.50 / 1.09$ & $5.56 / 2.49$ & $5.62 / 3.63$ & $5.67 / 4.72$ \\
\hline $\begin{array}{c}90 \mathrm{Mg}- \\
\mathrm{Ni}-\mathrm{Fe}-\mathrm{Ti} \\
(8 \mathrm{~h})\end{array}$ & $4.75 / 0.43$ & $4.90 / 0.91$ & $4.93 / 2.04$ & $4.99 / 2.99$ & $5.02 / 4.30$ \\
\hline
\end{tabular}

Fig. 7 exhibits the microstructures, observed by SEM, of the activated $90 \mathrm{Mg}-\mathrm{Ni}-\mathrm{Fe}-\mathrm{Ti}(4 \mathrm{~h})$ and $90 \mathrm{Mg}-\mathrm{Ni}-\mathrm{Fe}-\mathrm{Ti}$ $(8 \mathrm{~h})$ samples. The $90 \mathrm{Mg}-\mathrm{Ni}-\mathrm{Fe}-\mathrm{Ti}(8 \mathrm{~h})$ sample has fine particles. The $90 \mathrm{Mg}-\mathrm{Ni}-\mathrm{Fe}-\mathrm{Ti}(4 \mathrm{~h})$ sample has slightly larger particles than the $90 \mathrm{Mg}-\mathrm{Ni}-\mathrm{Fe}-\mathrm{Ti}(8 \mathrm{~h})$ sample. The particles of the samples are agglomerated. However, the particles of the $90 \mathrm{Mg}-\mathrm{Ni}-\mathrm{Fe}-\mathrm{Ti}(8 \mathrm{~h})$ sample are agglomerated more compactly than the $90 \mathrm{Mg}-\mathrm{Ni}-\mathrm{Fe}-\mathrm{Ti}$ (4 h) sample. The $90 \mathrm{Mg}-\mathrm{Ni}-\mathrm{Fe}-\mathrm{Ti}(4 \mathrm{~h})$ has some cracks.

The XRD patterns of the dehydrided $90 \mathrm{Mg}-\mathrm{Ni}-\mathrm{Fe}-\mathrm{Ti}$ (4 h) [23] and 90Mg-Ni-Fe-Ti (8 h) samples after activation are presented in Fig. 8. All the samples contain $\mathrm{Mg}, \mathrm{H}_{0.3} \mathrm{Mg}_{2} \mathrm{Ni}, \mathrm{MgH}_{2}, \mathrm{MgO}$, and Fe phases [25].

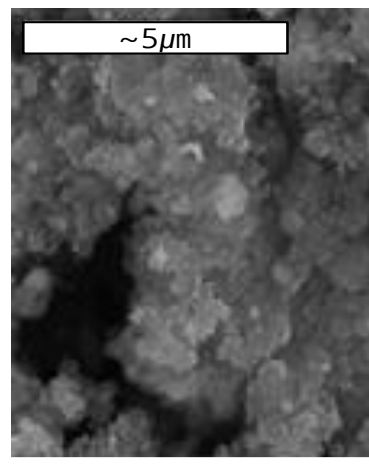

a

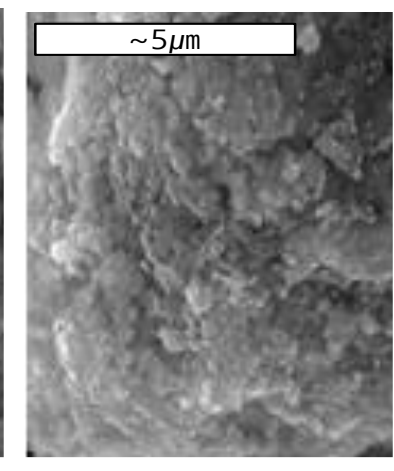

b
Fig. 7. Microstructures, observed by SEM, of the activated: a-90Mg-Ni-Fe-Ti (4 h); b-90Mg-Ni-Fe-Ti (8 h) samples

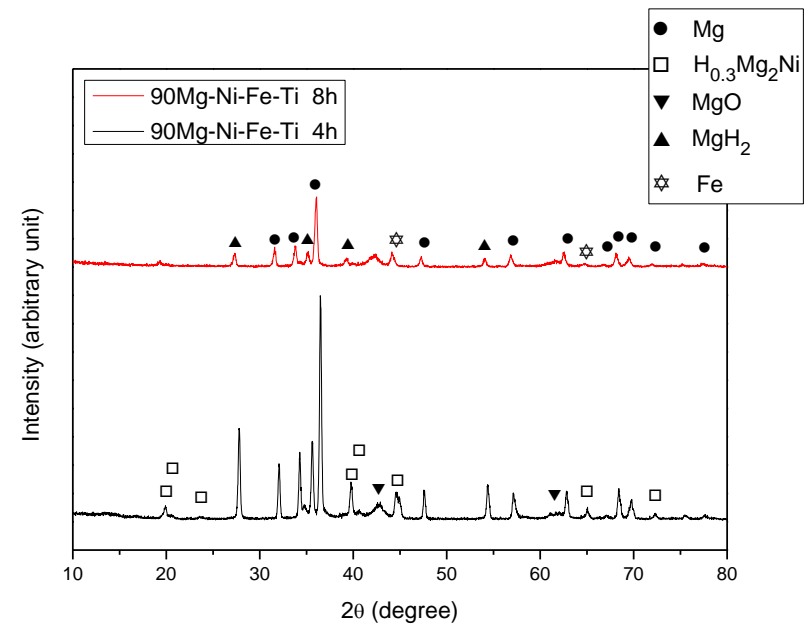

Fig. 8. XRD patterns of the dehydrided $90 \mathrm{Mg}-\mathrm{Ni}-\mathrm{Fe}-\mathrm{Ti}(4 \mathrm{~h})$ and $90 \mathrm{Mg}-\mathrm{Ni}-\mathrm{Fe}-\mathrm{Ti}(8 \mathrm{~h})$ samples after activation

$\mathrm{Mg}_{2} \mathrm{NiH}_{4}$, which has higher hydriding and dehydriding rates than magnesium [6], is believed to be formed after reactive mechanical grinding and hydriding reaction, by a reaction among $\mathrm{Ni}, \mathrm{Mg}$, and hydrogen. $\mathrm{Mg}_{2} \mathrm{NiH}_{4}$ then forms $\mathrm{H}_{0.3} \mathrm{Mg}_{2} \mathrm{Ni}$ after dehydriding reaction. The phases related to Ti could not be found, probably due to its small content. The added $\mathrm{Ti}$ was reported to form $\mathrm{Ti}$ hydride [11], which is brittle. The titanium hydride can be pulverized during reactive mechanical grinding and this pulverized titanium hydride can help $\mathrm{Mg}$ pulverized into finer particles. The titanium hydride can prevent the magnesium from being agglomerated by staying as a hydride among $\mathrm{Mg}$ particles.

In order to calculate the crystallite size and strain of $\mathrm{Mg}$ in the dehydrided samples after hydriding-dehydriding 
cycling, the Williamson-Hall method [23] is applied in which the following equation was used:

$B \cos \theta=K \lambda / t+4 \varepsilon \sin \theta$,

where $B$ is full width at half maximum (FWHM); $K$ shape factor (0.9); $\lambda$ wavelength (1.54056 $\AA$ ), t crystallite size, and $\varepsilon$ strain. The crystallite sizes of $\mathrm{Mg}$ in the dehydrided 90Mg-Ni-Fe-Ti (4 h) and 90Mg-Ni-Fe-Ti (8 h) samples after hydriding-dehydriding cycling were 49.7 and $37.0 \mathrm{~nm}$, respectively. The strains of $\mathrm{Mg}$ in the dehydrided 90Mg-Ni-Fe-Ti (4 h) and 90Mg-Ni-Fe-Ti (8 h) samples after hydriding-dehydriding cycling were 0.0088 and $0.0407 \%$, respectively. The order of the crystallite sizes of $\mathrm{Mg}$ in the dehydrided 90Mg-Ni-Fe-Ti (4 h) and $90 \mathrm{Mg}-\mathrm{Ni}-\mathrm{Fe}-\mathrm{Ti}(8 \mathrm{~h})$ samples after hydriding-dehydriding cycling is the same as that of the particle sizes observed by SEM (Fig. 7).

As mentioned above, the effect of reactive mechanical grinding on the hydriding rates of $90 \mathrm{Mg}-\mathrm{Ni}-\mathrm{Fe}-\mathrm{Ti}(8 \mathrm{~h})$ is stronger than that on those of $\mathrm{Mg}-5 \mathrm{Ni}-2.5 \mathrm{Fe}-2.5 \mathrm{Ti}(4 \mathrm{~h})$. On the other hand, the effect of hydriding-dehydriding cycling (due to the expansion of the $\mathrm{Mg}$ lattice by hydriding) on the hydriding rates of $90 \mathrm{Mg}-\mathrm{Ni}-\mathrm{Fe}-\mathrm{Ti}(4 \mathrm{~h})$ is stronger than that for $90 \mathrm{Mg}-\mathrm{Ni}-\mathrm{Fe}-\mathrm{Ti}(8 \mathrm{~h})$. Fig. 7 shows that the $90 \mathrm{Mg}-\mathrm{Ni}-\mathrm{Fe}-\mathrm{Ti}(4 \mathrm{~h})$ sample has slightly larger particles than the $90 \mathrm{Mg}-\mathrm{Ni}-\mathrm{Fe}-\mathrm{Ti}(8 \mathrm{~h})$ sample, but the particles of the $90 \mathrm{Mg}-\mathrm{Ni}-\mathrm{Fe}-\mathrm{Ti}(4 \mathrm{~h})$ sample are agglomerated less compactly than the $90 \mathrm{Mg}-\mathrm{Ni}-\mathrm{Fe}-\mathrm{Ti}(8 \mathrm{~h})$ sample and the $90 \mathrm{Mg}-\mathrm{Ni}-\mathrm{Fe}-\mathrm{Ti}(4 \mathrm{~h})$ has some cracks. Prolonged milling (for example, for $8 \mathrm{~h}$ ) is considered to bring about coalescence of particles which is caused by severe plastic deformation of ductile $\mathrm{Mg}$ particles. The stronger effect of hydriding-dehydriding cycling for $90 \mathrm{Mg}$ $\mathrm{Ni}-\mathrm{Fe}-\mathrm{Ti}$ (4 h) may be related to the less compact agglomeration of particles of this sample. The two points (the stronger effect of hydriding-dehydriding cycling and the less compact agglomeration) are believed to lead to the higher initial hydriding and dehydriding rates and the larger quantities of hydrogen absorbed and released for $60 \mathrm{~min}$ of $90 \mathrm{Mg}-\mathrm{Ni}-\mathrm{Fe}-\mathrm{Ti}(4 \mathrm{~h})$ than those of $90 \mathrm{Mg}-\mathrm{Ni}-\mathrm{Fe}-$ Ti $(8 \mathrm{~h})$ after $\mathrm{n}=2$.

90 wt. $\% \mathrm{Mg}+10 \mathrm{wt} \% \mathrm{Ni}$ alloy prepared by mechanical grinding in an Ar atmosphere absorbed about $4.45 \mathrm{wt} \% \mathrm{H}$ at $595 \mathrm{~K}$ under 11.7 bar $\mathrm{H}_{2}$ for 4 min [26]. Song et al. [27] studied hydrogen storage properties of an 80 wt.\% Mg+13.33 wt.\% Ni+6.67 wt.\% Fe alloy prepared via planetary ball milling in a $\mathrm{H}_{2}$ atmosphere. After activation, the sample absorbed $5.61 \mathrm{wt} \% \mathrm{H}$ for $60 \mathrm{~min}$ at $593 \mathrm{~K}$ under 12 bar $\mathrm{H}_{2}$ and desorbed $3.92 \mathrm{wt} \% \mathrm{H}$ for $30 \mathrm{~min}$ at $593 \mathrm{~K}$ under $1.0 \mathrm{bar} \mathrm{H}_{2}$. Our previous work [6] showed that $80 \mathrm{wt} \% \mathrm{Mg}+10 \mathrm{wt} . \% \mathrm{Ni}+5 \mathrm{wt} \% \mathrm{Fe}+$ $+5 \mathrm{wt} . \% \mathrm{Ti}$, prepared by reactive mechanical grinding, was activated after two hydriding-dehydriding cycles and absorbed 5.51 wt. $\% \mathrm{H}$ under 12 bar $\mathrm{H}_{2}$ and released 5.18 wt. $\% \mathrm{H}$ under 1.0 bar $\mathrm{H}_{2}$ at $573 \mathrm{~K}$ for $60 \mathrm{~min}$. The 80 wt.\% Mg+10 wt.\% Ni+5 wt.\% Fe+5 wt.\% Ti sample absorbed a smaller amount of hydrogen and released a larger amount of hydrogen than $90 \mathrm{Mg}-\mathrm{Ni}-\mathrm{Fe}-\mathrm{Ti}(4 \mathrm{~h})$ under the same conditions. It is thought that a larger content of $\mathrm{Mg}_{2} \mathrm{NiH}_{4}$ in 80 wt. $\% \quad \mathrm{Mg}+10$ wt. $\%$ $\mathrm{Ni}+5$ wt. $\% \mathrm{Fe}+5$ wt. $\%$ Ti than in $90 \mathrm{Mg}-\mathrm{Ni}-\mathrm{Fe}-\mathrm{Ti}(4 \mathrm{~h})$ led to the larger amount of the released hydrogen.
$\mathrm{Mg}_{2} \mathrm{NiH}_{4}$ has a higher dehydriding rate than $\mathrm{MgH}_{2}$. Lu et al. [3] investigated the hydriding characteristics of an 90 wt. $\% \mathrm{Mg}+10 \mathrm{wt} \%$ Ti alloy prepared by reactive mechanical grinding and hydrogen pulverization. They reported that the addition of titanium efficiently inhibited the oxidation of magnesium during alloying process, improved the hydrogen absorption capacity of $3.63 \mathrm{wt} . \%$ as compared with that of $\mathrm{Mg}$ (3.36 wt.\%), and decreased hysteresis. Palade et al. [7] prepared $\mathrm{Mg}-\mathrm{Ni}-\mathrm{Fe}$ alloys by melt spinning and subsequently ball milling. These alloys showed a better kinetic of hydrogendesorption than similar samples obtained by milling a mixture of $\mathrm{MgH}_{2}, \mathrm{Ni}$, and $\mathrm{Fe}$ commercial powders. They insisted that this may be explained by the presence in former samples of $\mathrm{Fe}$ at the $\mathrm{Mg}_{2} \mathrm{Ni}$ grain boundaries, with catalytic effect on the gassolid reaction. Meyer and Mendoza-Zélis [8] studied the hydrogen sorption properties of mechanically alloyed $\mathrm{Mg}_{1-2 \mathrm{x}} \mathrm{Fe}_{\mathrm{x}} \mathrm{Ti}_{\mathrm{x}}$ powder mixtures. They concluded that the simultaneous presence of $\mathrm{Fe}$ and $\mathrm{Ti}$ does not imply a beneficial effect on their catalytic action in powder samples, but $\mathrm{Fe}$ alone produce adequate microstructures under a controlled decomposition of mechanically produced $\mathrm{Mg}_{2} \mathrm{FeH}_{6}$, and $\mathrm{Ti} / \mathrm{TiH}_{2}$ have been demonstrated recently to be a promising alternative.

\section{CONCLUSIONS}

Reactive mechanical grinding for a longer time (for $8 \mathrm{~h}$ ), compared with that for $4 \mathrm{~h}$, intensified the effects of reactive mechanical grinding. The effects of of hydridingdehydriding cycling on the hydriding and dehydriding rates of $90 \mathrm{Mg}-\mathrm{Ni}-\mathrm{Fe}-\mathrm{Ti}(4 \mathrm{~h})$ and $90 \mathrm{Mg}-\mathrm{Ni}-\mathrm{Fe}-\mathrm{Ti}(8 \mathrm{~h})$ were very strong from $n=1$ to $n=2$. The complete activation of the samples was achieved after about three hydridingdehydriding cycles. The dehydrided $90 \mathrm{Mg}-\mathrm{Ni}-\mathrm{Fe}-\mathrm{Ti}(4 \mathrm{~h})$ and $90 \mathrm{Mg}-\mathrm{Ni}-\mathrm{Fe}-\mathrm{Ti}(8 \mathrm{~h})$ samples after activation contained $\mathrm{Mg}, \mathrm{H}_{0.3} \mathrm{Mg}_{2} \mathrm{Ni}, \mathrm{MgH}_{2}, \mathrm{MgO}$, and $\mathrm{Fe}$ phases. After activation, 90Mg-Ni-Fe-Ti $(4 \mathrm{~h})$ had higher initial hydriding and dehydriding rates and larger quantities of hydrogen absorbed and released for $60 \mathrm{~min}$ than $90 \mathrm{Mg}-\mathrm{Ni}-\mathrm{Fe}-\mathrm{Ti}(8 \mathrm{~h})$. The activated $90 \mathrm{Mg}-\mathrm{Ni}-\mathrm{Fe}-\mathrm{Ti}(4 \mathrm{~h})$ sample absorbed $5.21 \mathrm{wt} . \% \mathrm{H}$ for $5 \mathrm{~min}$ and $5.67 \mathrm{wt} . \% \mathrm{H}$ for $60 \mathrm{~min}$ at $573 \mathrm{~K}$ under $12 \mathrm{bar} \mathrm{H}_{2}$ and released $1.09 \mathrm{wt} . \% \mathrm{H}$ for $10 \mathrm{~min}$ and $4.72 \mathrm{wt} . \% \mathrm{H}$ for $60 \mathrm{~min}$ at $573 \mathrm{~K}$ under 1.0 bar $\mathrm{H}_{2}$. Prolonged milling (for example, for $8 \mathrm{~h}$ ) is considered to bring about coalescence of particles which is caused by severe plastic deformation of ductile $\mathrm{Mg}$ particles. The stronger effect of hydridingdehydriding cycling for $90 \mathrm{Mg}-\mathrm{Ni}-\mathrm{Fe}-\mathrm{Ti}(4 \mathrm{~h})$ may be related to the less compact agglomeration of particles of this sample. The two points (the stronger effect of hydriding-dehydriding cycling and the less compact agglomeration) are believed to lead to the higher initial hydriding and dehydriding rates and the larger quantities of hydrogen absorbed and released for $60 \mathrm{~min}$ of $90 \mathrm{Mg}-\mathrm{Ni}-$ $\mathrm{Fe}-\mathrm{Ti}(4 \mathrm{~h})$ than those of $90 \mathrm{Mg}-\mathrm{Ni}-\mathrm{Fe}-\mathrm{Ti}(8 \mathrm{~h})$ after $\mathrm{n}=2$.

\section{Acknowledgments}

This research was performed for the Hydrogen Energy R\&D Center, one of the 21 st Century Frontier R\&D 
Programs, funded by the Ministry of Science and Technology of Republic of Korea.

\section{REFERENCES}

1. Züttel, A. Materials for Hydrogen Storage Materials Today 6 (9) 2003: pp. 24-33. https://doi.org/10.1016/S1369-7021(03)00922-2

2. Krozer, A., Kasemo, B. Equilibrium Hydrogen Uptake and Associated Kinetics for the Magnesium-Hydrogen System at Low Pressures Journal of Physics: Condensed Matter 1 (8) 1989: pp. $1533-1538$.

https://doi.org/10.1088/0953-8984/1/8/017

3. Lu, W.C., Ou, S.F., Lin, M.H., Wong, M.F. Hydriding Characteristics of Mg-Ti Alloys Prepared by Reactive Mechanical Grinding and Hydrogen Pulverization Journal of Alloys and Compounds 664 2016: pp. 193-198. https://doi.org/10.1016/j.jallcom.2015.12.064

4. Stillesjoe, F., Olafsson, S., Hjoervarsson, B., Karlsson, E. Hydride Formation in $\mathrm{Mg} / \mathrm{Ni}$-Sandwiches Studied by Hydrogen Profiling and Volumetric Measurement Zeitschrift für Physikalische Chemie $181(1-2)$ 1993: pp. 353-358. https://doi.org/10.1524/zpch.1993.181.Part_1_2.353

5. Bobet, J.L., Akiba, E., Nakamura, Y., Darriet, B. Study of $\mathrm{Mg}-\mathrm{M}(\mathrm{M}=\mathrm{Co}, \mathrm{Ni}$ and $\mathrm{Fe})$ Mixture Elaborated by Reactive Mechanical Alloying-Hydrogen Sorption Properties International Journal of Hydrogen Energy 25 2000: pp. $987-996$. https://doi.org/10.1016/S0360-3199(00)00002-1

6. Kwon, S.N., Baek, S.H., Mumm, D.R., Hong, S.H., Song, M.Y. Enhancement of the Hydrogen Storage Characteristics of $\mathrm{Mg}$ by Reactive Mechanical Grinding with $\mathrm{Ni}, \mathrm{Fe}$ and $\mathrm{Ti}$ International Journal of Hydrogen Energy 33 2008: pp. $4586-4592$. https://doi.org/10.1016/j.ijhydene.2008.05.097

7. Palade, P., Sartori, S., Maddalena, A., Principi, G., Lo Russo, S., Lazarescu, M., Schinteie, G., Kuncser, V., Filoti, G. Hydrogen Storage in $\mathrm{Mg}-\mathrm{Ni}-\mathrm{Fe}$ Compounds Prepared by Melt Spinning and Ball Milling Journal of Alloys and Compounds 415 2006: pp. 170-176. https://doi.org/10.1016/j.jallcom.2005.08.017

8. Meyer, M., Mendoza-Zélis, L. Hydrogen Sorption Properties of Mechanically Alloyed $\mathrm{Mg}_{1-2 x} \mathrm{Fe}_{\mathrm{x}} \mathrm{Ti}_{\mathrm{x}}$ Powder Mixtures Journal of Alloys and Compounds 611 2014: pp. 11-18. https://doi.org/10.1016/j.jallcom.2014.05.105

9. Huot, J., Tremblay, M.L., Schulz, R. Synthesis of Nanocrystalline Hydrogen Storage Materials Journal of Alloys Compounds 356-357 2003: pp. 603-607. https://doi.org/10.1016/S0925-8388(03)00120-8

10. Imamura, H., Kusuhara, M., Minami, S., Matsumoto, M., Masanari, K., Sakata, Y., Itoh, K, Fukunaga, T. Carbon Nanocomposites Synthesized by High-Energy Mechanical Milling of Graphite and Magnesium for Hydrogen Storage Acta Materialia 51 (20) 2003: pp. 6407-6414. https://doi.org/10.1016/j.actamat.2003.08.010

11. Kwon, S.N., Park, H.R., Song, M.Y. Hydrogen Storage and Release Properties of Transition Metal-Added Magnesium Hydride Alloy Fabricated by Grinding in a Hydrogen Atmosphere Korean Journal of Metals and Materials 54 2016: pp. 510-519.

12. Mumm, D.R., Kwak, Y.J., Park, H.R., Song, M.Y. Effects of Milling and Hydriding-Dehydriding Cycling on the HydrogenStorage Behaviors of a Magnesium-Nickel-Tantalum Fluoride Alloy Korean Journal of Metals and Materials 53 2015: pp. $904-910$.

https://doi.org/10.3365/KJMM.2015.53.12.904

13. Lee, S.H., Park, H.R., Song, M.Y. Change in HydrogenStorage Performance of Transition Metals and $\mathrm{NaAlH}_{4}$-Added
$\mathrm{MgH}_{2}$ with Thermal and Hydriding-Dehydriding Cycling Korean Journal of Metals and Materials 53 2015: pp. $133-138$.

14. Mumm, D.R., Lee, S.H., Song, M.Y. Cycling Behavior of Transition Metals and Sodium Alanate-Added $\mathrm{MgH}_{2} \mathrm{Kept}$ in a Glove Box Korean Journal of Metals and Materials 53 2015: pp. 584-590.

15. Song, M.Y., Kwak, Y.J., Park, H.R. Hydrogen Storage Characteristics of Metal Hydro-Borate and Transition ElementAdded Magnesium Hydride Korean Journal of Metals and Materials 54 2016: pp. 503-509.

16. Lee, S.H., Kwak, Y.J., Park, H.R., Song, M.Y. Enhancement of the Hydriding and Dehydriding Rates of $\mathrm{Mg}$ by Adding $\mathrm{TiCl}_{3}$ and Reactive Mechanical Grinding Korean Journal of Metals and Materials 53 2015: pp. 187-192. https://doi.org/10.3365/KJMM.2015.53.3.187

17. Park, H.R., Kwak, Y.J., Lee, S.H., Song, M.Y. Hydrogen Sorption of Pure Mg, and Niobium (V) Fluoride-Added Mg Alloys Prepared by Planetary Ball Milling in Hydrogen Korean Journal of Metals and Materials 54 2016: pp. 916-924.

18. Hong, S.H., Song, M.Y. Study on the Reactivity with Hydrogen of Planetary Ball Milled 90 wt.\% Mg+10 wt.\% $\mathrm{MgH}_{2}$ : Analyses of Reaction Rates with Hydrogen and Microstructure Korean Journal of Metals and Materials 54 2016: pp. 358-363.

19. Hjort, P., Krozer, A., Kasemo, B. Hydrogen Sorption Kinetics in Partly Oxidized Mg Films Journal of Alloys Compounds $237(1-2)$ 1996: pp. 74-80. https://doi.org/10.1016/0925-8388(95)02165-5

20. Zaluska, A., Zaluski, L., Ström-Olsen, J.O. Nanocrystalline Magnesium for Hydrogen Storage Journal of Alloys Compounds 288 1999: pp. 217-225.

https://doi.org/10.1016/S0925-8388(99)00073-0

21. Vigeholm, B., $\quad$ Kjoller, J., $\quad$ Larsen, B., $\quad$ Pedersen, A.S. Formation and Decomposition of Magnesium Hydride Journal of the Less-Common Metals 89 (1) 1983: pp. $135-144$. https://doi.org/10.1016/0022-5088(83)90259-X

22. Song, M.Y., Pezat, M., Darriet, B., Hagenmuller, $\mathbf{P}$. Hydriding Mechanism of $\mathrm{Mg}_{2} \mathrm{Ni}$ in the Presence of Oxygen Impurity in $\mathrm{H}_{2}$ Journal of Materials Science 20 1985: pp. $2958-2964$. https://doi.org/10.1007/BF00553060

23. Song, M.Y., Park, H.R., Kwon, S.N. Evaluation of the Metaladded $\quad \mathrm{Mg}$ Hydrogen Material and Comparison with the Oxide-Added Mg Journal of Industrial and Engineering Chemistry 21 2015: pp. $378-386$. https://doi.org/10.1016/j.jiec.2014.02.048

24. Song, M.Y., Kwon, I.H., Kwon, S.N., Park, C.G., Park, H.R., Bae, J.S. Preparation of Hydrogen-Storage Alloy Mg?10wt\% $\mathrm{Fe} 2 \mathrm{O} 3$ under Various Milling Conditions International Journal of Hydrogen Energy 31 2006: pp. $43-47$. https://doi.org/10.1016/j.ijhydene.2005.03.008

25. Song, M.Y., Kwon, S.N., Hong, S.H., Park, H.R. Hydrogen Storage Properties of a Ni, Fe and Ti-Added Mg-Based Alloy Metals and Materials International 18 2012: pp. 279-286. https://doi.org/10.1007/s12540-012-2011-9

26. Song, M.Y. Hydriding Kinetics of a Mechanically Alloy ed Mixture Mg-10wt\% Ni International Journal of Hydrogen Energy 28 2003: pp. $403-408$. https://doi.org/10.1016/S0360-3199(02)00133-7

27. Song, M.Y., Baek, S.H., Bobet, J.L., Hong, S.H. Hydrogen Storage Properties of a Mg-Ni-Fe Mixture Prepared via Planetary Ball Milling in a $\mathrm{H} 2$ Atmosphere International Journal of Hydrogen Energy 35 2010: pp. 10366-10372. https://doi.org/10.1016/j.ijhydene.2010.07.161 